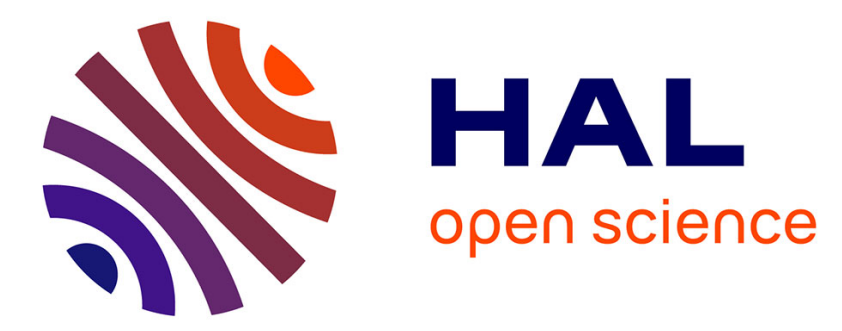

\title{
The assessment of vitellogenin as a biomarker of exposure to estrogenic compounds in two Australian perciformes
}

Susan Codi King, Kathryn A. Hassell, Dayanthi Nugegoda, Sven Inge

Kristiansen

\section{To cite this version:}

Susan Codi King, Kathryn A. Hassell, Dayanthi Nugegoda, Sven Inge Kristiansen. The assessment of vitellogenin as a biomarker of exposure to estrogenic compounds in two Australian perciformes. Marine Environmental Research, 2008, 66 (1), pp.116. 10.1016/j.marenvres.2008.02.040 . hal-00563015

\section{HAL Id: hal-00563015 https://hal.science/hal-00563015}

Submitted on 4 Feb 2011

HAL is a multi-disciplinary open access archive for the deposit and dissemination of scientific research documents, whether they are published or not. The documents may come from teaching and research institutions in France or abroad, or from public or private research centers.
L'archive ouverte pluridisciplinaire HAL, est destinée au dépôt et à la diffusion de documents scientifiques de niveau recherche, publiés ou non, émanant des établissements d'enseignement et de recherche français ou étrangers, des laboratoires publics ou privés. 


\section{Accepted Manuscript}

The assessment of vitellogenin as a biomarker of exposure to estrogenic compounds in two Australian perciformes

Susan Codi King, Kathryn Hassell, Dayanthi Nugegoda, Sven Inge Kristiansen

PII: S0141-1136(08)00046-9

DOI: 10.1016/j.marenvres.2008.02.040

Reference: MERE 3198

To appear in: Marine Environmental Research

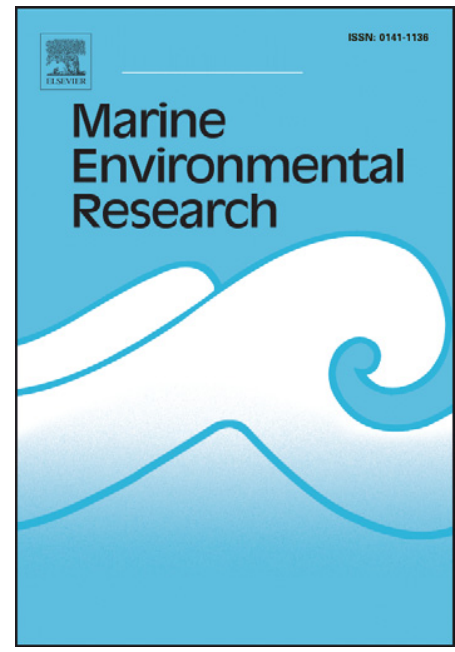

Please cite this article as: King, S.C., Hassell, K., Nugegoda, D., Kristiansen, S.I., The assessment of vitellogenin as a biomarker of exposure to estrogenic compounds in two Australian perciformes, Marine Environmental Research (2008), doi: 10.1016/j.marenvres.2008.02.040

This is a PDF file of an unedited manuscript that has been accepted for publication. As a service to our customers we are providing this early version of the manuscript. The manuscript will undergo copyediting, typesetting, and review of the resulting proof before it is published in its final form. Please note that during the production process errors may be discovered which could affect the content, and all legal disclaimers that apply to the journal pertain. 


\title{
The assessment of vitellogenin as a biomarker of exposure to
} estrogenic compounds in two Australian perciformes

\section{Susan Codi King ${ }^{\mathrm{a}, *}$, Kathryn Hassell ${ }^{\mathrm{b}}$, Dayanthi Nugegoda ${ }^{\mathrm{b}}$, Sven Inge Kristiansen $^{c}$}

\author{
${ }^{a}$ Australian Institute of Marine Science, PMB\#3, Townsville, Qld 4810, Australia \\ ${ }^{b}$ Biotechnology and Environmental Biology, School of Applied Sciences, RMIT University, PO Box 71, Bundoora, \\ Vic 3083, Australia \\ ${ }^{c}$ Biosense Laboratories AS, HIB-Thormфhlensgt. 55, N-5008 Bergen, Norway
}

\begin{abstract}
Vitellogenin (Vtg) is a yolk protein precursor that has been identified as a sensitive biomarker for exposure to estrogenic compounds. We evaluated specific monoclonal and polyclonal antibodies for reactivity with plasma Vtg from two Australian Perciformes, the tropical barramundi (Lates calcarifer) and the temperate black bream (Acanthopagrus butcheri). Blood plasma from $17 \beta$-estradiol exposed $\left(\mathrm{E}_{2}\right)$ male barramundi $\left(20 \mathrm{mg} \mathrm{kg}^{-1}\right)$ and male black bream (2.5-5.0 mg kg-1) were sent to Biosense Laboratories (Norway) for cross-reactivity testing using their extensive anti-Vtg antibody selection. Indirect ELISA results determined barramundi plasma displayed the highest binding affinities to ND-3G2 (monoclonal-Mab) and PO-1
\end{abstract}


(polyclonal-Pab). Black bream was most cross-reactive with ND-IC8 (Mab) and PO-2 (Pab). Next, plasma was assessed for Vtg induction in $\mathrm{E}_{2}$-dosed $\left(5 \mathrm{mg} \mathrm{kg}^{-1}\right)$, hatchery-reared barramundi and black bream versus a non-injected control group. Vtg production was assessed by Western blot and indirect ELISA using ND-3G2 and ND-IC8 Mabs, respectively. A prominent band was identified in the range of $100-200 \mathrm{kDa}$ for all female black bream and for all $\mathrm{E}_{2}$-treated barramundi and black bream males, which was confirmed as Vtg by Western blot. Indirect ELISA results for barramundi demonstrated highly significant differences in $\mathrm{E}_{2}$-dosed fish as compared to control fish (Student $t, \mathrm{P}=0.001$ ). $\mathrm{E}_{2}$ male black bream were significantly different than control males (Student $t, \mathrm{P}<0.001$ ) and control and $\mathrm{E}_{2}$ females displayed highly significant differences (Student $t, \mathrm{P}<0.001$ ). These results indicate that exposure to $17 \beta$-estradiol induces significant Vtg production in males of the two Australian Perciformes, with potential use as a biomarker for exposure to estrogenic compounds.

Keywords: Vtg; ELISA; Fish; Estrogens; Western blot; Biomarkers

Corresponding author: Email address: s.codiking@aims.gov.au (S. Codi King) 
In preparation for oocyte development, a series of hormonal processes occur in oviparous female fish resulting in production of ovarian estrogen which is transported to the liver to encounter hepatic estrogen receptors and stimulate production of vitellogenin (Specker and Sullivan, 1994; Jobling, 1995; Kime et al., 1999). Vitellogenin (Vtg) is a complex phospholipoglycoprotein that is transported to the ovary via the bloodstream where it is incorporated into developing oocytes (Specker and Sullivan, 1994; Jobling, 1995). This process, called vitellogenesis, normally occurs only in mature females that are able to produce sufficient levels of ovarian estrogen; however, exposure to estrogenic compounds (including agonistic contaminants) can stimulate vitellogenin production in juvenile and male fish, since they also have hepatic estrogen receptors (Specker and Sullivan, 1994; Denslow et al., 1999; Kime et al., 1999). This study investigated Vtg induction in two key Australian Perciformes for the first time as a potential biomarker of exposure to estrogenic compounds.

Hatchery-reared male barramundi and male black bream were administered $17 \beta$-estradiol by intraperitoneal (ip) injections at doses of $20 \mathrm{mg} \mathrm{kg}^{-1}$ and $2.5-5.0 \mathrm{mg} \mathrm{kg}^{-1}$, body weight, respectively. Fish were anaesthetized then bled by caudal puncture using syringes lased with heparin. Plasma was collected by centrifugation and snap frozen in liquid nitrogen. Samples were shipped on dry ice to Biosense Laboratories in Norway where cross-reactivity was tested against a range of different antibodies for each species at various dilutions to optimize assay conditions. For barramundi anti-Vtg antibodies tested were from: Morone saxitilis (Perciformes) (ND-3G2); Fundulus heteroclitus (Cypriniformes) (ND-5F8); Salmo salar (Salmoniformes) (BN5); Gasterosteus aculeatus (Gasterosteiformes) (Stb-pAn); Salvelinus alpinus (Salmoniformes) (PO-1); and Salmo salar (Salmoniformes) (AA-1). For black bream they were from: Morone saxitilis (Perciformes) (ND-1C8); Morone saxitilis (Perciformes) (ND-3G2); Sparus aurata (Perciformes) (PO-2); Gadus morhua (Gadiformes) (CS-1); Scophthalmus maximus 
(Pleuronectiformes) (CS-2); and Anarhichas lupus (Perciformes) (CS-3). Two different Morone saxitilis anti-Vtg monoclonal antibodies are commercially available, and each recognizes a different epitope of the Vtg protein. ND-1C8 binds with intact Vtg, whilst ND-3G2 binds with both intact and degraded Vtg, from a range of fish species (Biosense Laboratories). Indirect ELISA and Western blot assays were conducted in Norway according to the standard operating $\begin{array}{llll}\text { procedure } & \text { described } & \text { by } & \text { Biosense }\end{array}$ www.biosense.com/docs/Biomarker_ELISA_protocol.pdf). In Australia, semi-quantitative indirect ELISA was performed using the same method. Western blots were prepared using a Mini-PROTEAN III/ Mini Trans-Blot unit (Bio-Rad, Australia), according to the manufacturer's instructions, and the same primary antibodies as used for ELISA. Plasma was loaded at $10 \mu \mathrm{g}$ protein per lane for barramundi and $1 \mu \mathrm{g}$ protein per lane for black bream. The WesternBreeze ${ }^{\circledR}$ Chromogenic Kit (Invitrogen, Australia) was used for detection.

The ELISA assay was optimized for sample and antibody dilutions. Titration curves for plasma revealed the highest binding affinities to the monoclonal antibody (Mab, ND-3G2) and polyclonal antibody (Pab, PO-1) for barramundi and to ND-IC8 (Mab) and PO-2 (Pab) for black bream (Fig 1). ELISA results for barramundi (Fig 2A) showed that three Mabs; ND-3G2, ND5F8 and BN-5 gave optimum binding (absorbance at $492 \mathrm{~nm}$ - non-specific binding) above their corresponding controls. For the Pabs, PO-1 bound most strongly compared to the control and exhibited similar binding capacity to the Mabs (Fig 2A). Vtg production in $\mathrm{E}_{2}$-dosed barramundi was confirmed by Western blot (Fig 2B). Interestingly, the ELISA results for BN-5 were not confirmed by Western blot, which indicated no Vtg band. The binding observed in the ELISA is thus non-specific and highlights the importance of using a second detection technique (such as Western blot) to confirm the presence of Vtg. Similar analysis for $E_{2}$-dosed black bream 
compared to non- injected controls (results not presented), providing the necessary background data for subsequent validation studies.

Laboratory validation studies were conducted in Australia by assessing Vtg induction with Western blot and ELISA in $\mathrm{E}_{2}$-dosed male barramundi and male and female black bream using the Mabs, ND-3G2 and ND-1C8, respectively, compared to non-injected controls. For consistency, both species were assessed with the anti-Vtg Mabs that displayed the highest binding affinities for each species. Western blots revealed a specific protein band that only occurred in $E_{2}$-dosed male fish of both species and female black bream. In black bream the band was more pronounced in females following $\mathrm{E}_{2}$-dosing. The molecular weight of this protein was determined to be in the range of $100-200 \mathrm{kDa}$ which is in agreement with other reported size estimations for denatured (or subunit) Vtg ( Specker and Sullivan, 1994; Denslow et al., 1999) and consistent with Western blot data as shown in Fig 2B. Semi-quantitative ELISA revealed significant differences in Vtg levels between control and $\mathrm{E}_{2}$-dosed samples of both barramundi (P $=0.001)$ and black bream $(\mathrm{P}<0.001)$. In $\mathrm{E}_{2}$-dosed black bream, there were no significant differences in Vtg levels between the two sexes $(\mathrm{P}=0.485)$.

Vtg induction as a sensitive biomarker of exposure to estrogenic compounds has not been previously evaluated in these two Australian Perciformes. Exposure to 17 $\beta$-estradiol, one of the most potent inducers of Vtg synthesis and secretion in vivo (Tilton et al., 2001) resulted in Vtg production in males of both species. Work conducted in Norway and validated in Australia showed Vtg induction in male barramundi and black bream using the monoclonal antibodies ND3G2 and ND-1C8, respectively. Results were confirmed using two different but equally sensitive detection techniques, ELISA and Western blot. In both species, significant differences between $17 \beta$-estradiol exposed and control fish were observed and Western blotting produced a distinct Vtg band. These results suggest that Vtg production has potential as a biomarker for exposure to 
estrogenic compounds in the tropical barramundi and the temperate black bream and assessment of this biomarker in fish populations exposed to contaminants in Australian waters is underway.

\section{Acknowledgements}

This work was supported by AIMS and the School of Applied Sciences, RMIT University. KH was in receipt of an Australian Postgraduate Award. We thank Fiona Baird and Edward Grixti (RMIT University) for technical assistance and Dr. Andrew Negri for constructive comments on this manuscript.

\section{References}

Denslow, N.D., Chow, M.C., Kroll, K.J., and Green, L. (1999). Ecotoxicology, 8, 385-398.

Jobling, M. (1995). Environmental Biology of Fishes: Chapman and Hall, London, 455 pp.

Kime, D.E., Nash, J.P., and Scott, A.P. (1999). Aquaculture, 177, 345-352.

Specker, J.L., and Sullivan, C.V. (1994). In Perspectives in Comparative Endocrinology, eds K.G. , Davey et al., pp 304-315. National Research Council Canada, Ottawa.

Tilton, F., Benson, W.H., and Schlenk, D. (2001). Environmental Toxicology and Pharmacology, 9, 169-172. 


\section{Figure Captions}

Fig. 1. Titration curves for $\mathrm{E}_{2}$-dosed barramundi (A) and black bream (B), determined by indirect ELISA using selected monoclonal (Mab) and polyclonal (Pab) antibodies. Shaded symbols represent Mabs and hollow symbols represent Pabs. Mab used indicated by solid line.

Fig 2. (A) Indirect ELISA results for Vtg measurement in $E_{2}\left(20 \mathrm{mg} \mathrm{kg}^{-1}\right)$ plasma of barramundi compared to $\mathrm{C}$ (control) plasma using a suite of Mabs and Pabs. (B) Confirmation of the production of Vtg using Western blot in plasma of $\mathrm{E}_{2}$-dosed barramundi compared to control plasma using the same suite of Mabs and Pabs used in the ELISA assays.Figure 1. 
Figure 1.
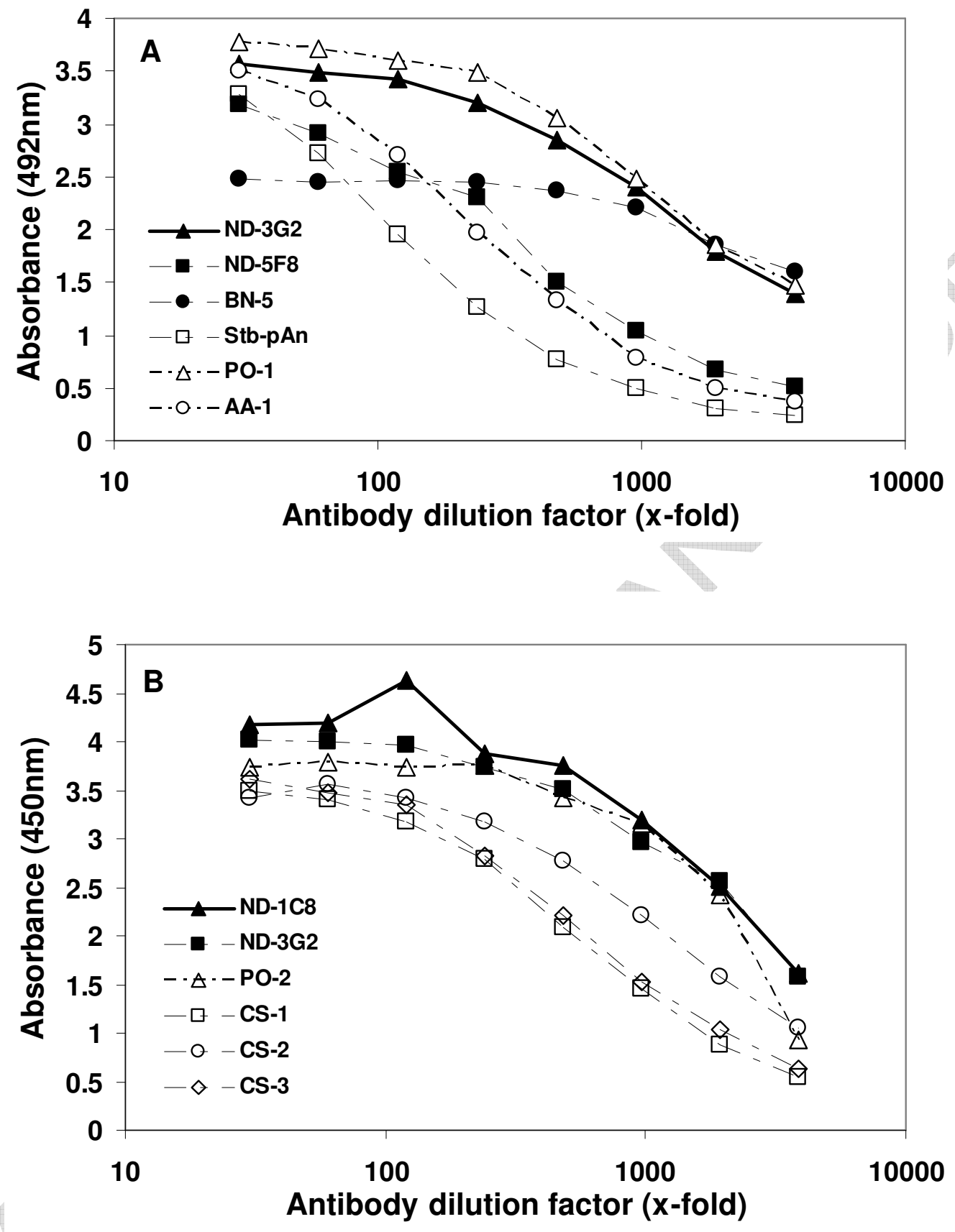
Figure 2

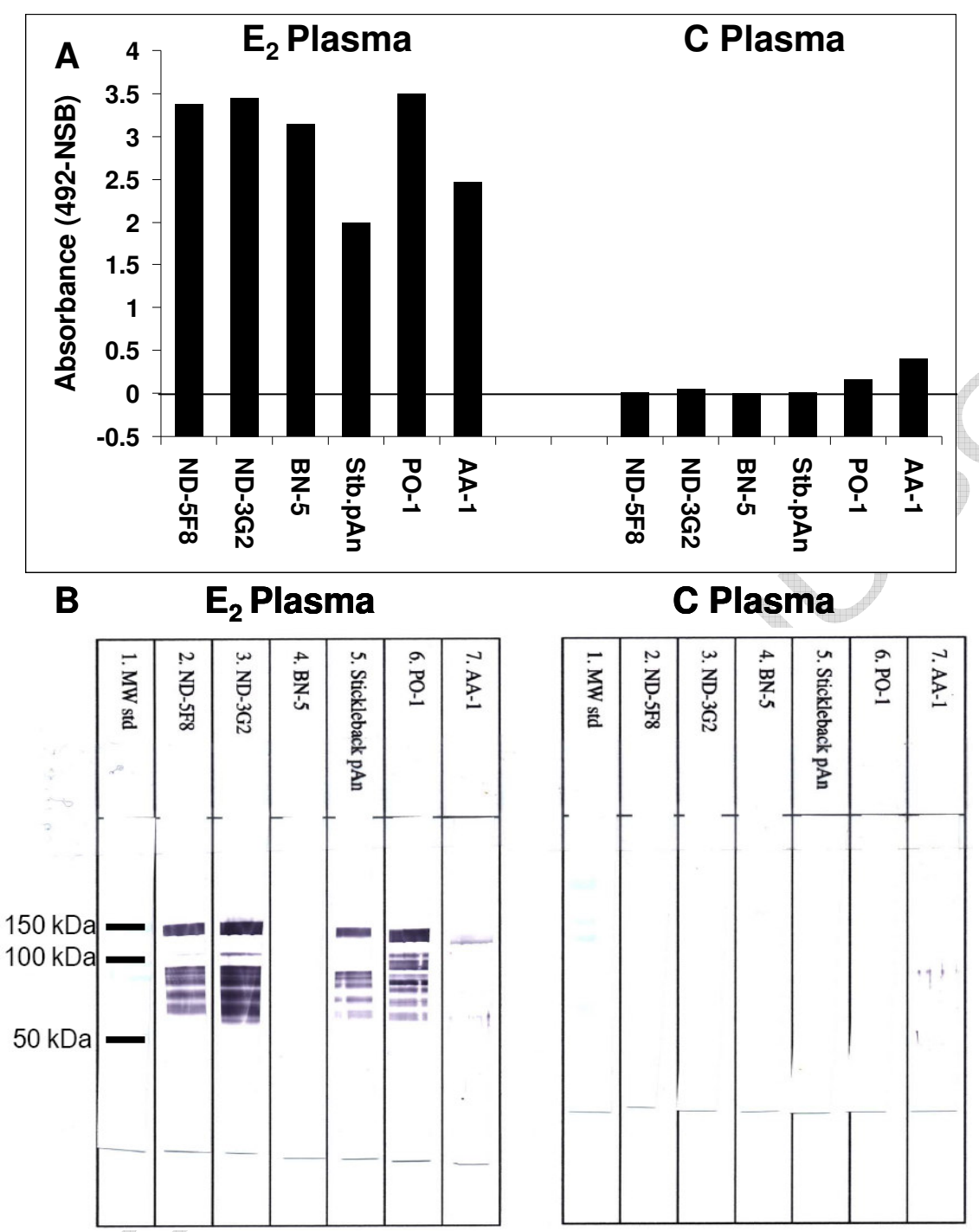

